\title{
The acceptable face of capitalism: law, corporations and economic wellbeing
}

Wanjiru Njoya, Senior Lecturer, University of Exeter Law School

\begin{abstract}
In response to concerns that capitalism yields prosperity only at the cost of rising inequality, this paper draws upon examples from employment law and corporate governance to argue that the legal framework should reflect a broad understanding of economic wellbeing that encompasses both the costs and the benefits of corporate activity. To the extent that economic growth expands the scope of corporate welfare provision for employees in large firms, the preoccupation with distributive matters such as executive pay ratios is misplaced; in this context the ideal of equality matters not for its own sake but more because it offers a means of achieving human flourishing and fuller participation in social and economic life. The paper shows how this insight would help to ease the growing financial pressure on state-guaranteed social security, particularly in the context of increasing numbers of selfemployed workers in the gig economy.
\end{abstract}

\section{Key words}

capitalism, employees, corporate governance, regulation, redistribution, welfare state 


\section{The acceptable face of capitalism: law, corporations and economic wellbeing}

Wanjiru Njoya ${ }^{1}$

\section{Introduction: the two faces of capitalism}

'Inequality is the handmaiden of progress'. ${ }^{2}$

Capitalism is lauded for its associations with liberty, progress and prosperity; it is derided for being oblivious to glaring social and economic inequality. How should we evaluate the benefit of progress, if it appears to come at an unacceptable social cost? More specifically, when should law intervene in the interests of advancing the goals of social justice? These questions lie at the heart of global concerns about economic development. It may well be the case that Victorian England exhibited the worst excesses of unregulated and exploitative industrialization, or that modern CEOs portray the 'unacceptable face of capitalism' ${ }^{3}$ in one scandal after the other when they profit at the expense of the corporation, its workers and the wider society. But it is to twenty-first century Africa that we should look in order fully to appreciate the grim realities in jurisdictions where competitive capitalism has yet to put down secure and independent roots. ${ }^{4}$ In The Truth About Markets John Kay recounts the experience of Tanzania under the leadership of Julius Nyerere, the illustrious president who sought to bring progress to his beautiful but impoverished pre-industrial country by prioritizing social

\footnotetext{
${ }^{1}$ University of Exeter, UK. Email: w.n.njoya@exeter.ac.uk. I am grateful to Bruce Pardy for many helpful discussions on the themes of this paper. I am also grateful to Marc Moore and the Editor of the Kings Law Journal for helpful comments on previous drafts.

${ }^{2}$ A Deaton, The Great Escape: Health, Wealth, and the Origins of Inequality (Princeton University Press 2013), 6: In this study Deaton highlights both progress and inequality: 'I tell the story of material progress, but that story is one of both growth and inequality' (emphasis in the original).

${ }^{3}$ House of Commons, BHS: First Report of the Work and Pensions Committee and Fourth Report of the Business, Innovation and Skills Committee of Session 2016-17 (20 July, 2016) par 168.

${ }^{4}$ In this discussion capitalism refers to 'competitive capitalism - the organization of the bulk of economic activity through private enterprise operating in a free market - as a system of economic freedom and a necessary condition for political freedom': M Friedman, Capitalism and Freedom (University of Chicago Press 1962) 2002 edition, 4. Therefore, 'capitalism' is not simply shorthand for the 'very greedy people' or 'unrestrained individualism' associated with corrupt third world governments as depicted by J Kay, The Truth about Markets: Why Some Nations are Rich but Most Remain Poor (London, Penguin Books 2003) 8-10 and 273-274; on the contrary, 'unrestrained greed' and 'weak government' are antithetical to free market ideals.
} 
welfare and attempting to avoid the unpleasantness of the dark side of capitalism. ${ }^{5}$ Nyerere abhorred the individualism of private property rights and encouraged community living based on joint effort for the common good. ${ }^{6}$ The experiment did not end well and Tanzania's economy is still mired in poverty, disproportionately dependent on agriculture and foreign aid. The causes of economic failure are complex and multi-faceted, but Tanzania's experience offers a poignant illustration of Kay's point about the embeddedness of capitalist markets within the broader institutional framework: the legal, cultural, historical and political context within which markets function is just as important as, and perhaps even more important than, the processes of technological innovation and productive exchange. ${ }^{7}$ In that context, it is clear that legal rules strongly influence economic outcomes. For those concerned with economic development the implication is that a comprehensive account of the role played by legal institutions in facilitating growth and prosperity is essential in evaluating the integrity and sustainability of the capitalist model.

With that in mind this discussion turns the spotlight onto the legal regulation of a particularly important facet of market exchange, namely the exchange between labour and capital. In common law jurisdictions that exchange is primarily regulated by labour and employment law, complemented by other fields governing specific interactions between employer and employee such as company law, tax law, social security and pensions regulations. Any attempt to evaluate the effectiveness of policies designed to support economic progress, together with the attendant social welfare safeguards, requires this broad range of legal principles to be understood as a coherent whole. Yet the legal framework is too often fragmented into

\footnotetext{
${ }^{5}$ Kay (ibid): 'Julius Nyerere stands out among the corrupt and vainglorious politicians of modern Africa for his decency and integrity. A socialist who believed in planned development, he devoted himself to the welfare of his people in twenty-one years as president', 271. Nyerere was a graduate of the University of Edinburgh, where he read Economics and History, and was subsequently leader of Tanzania between 1961 and 1985.

${ }^{6}$ The issue, as Nyerere saw it, was how to adopt the benefits of capitalism without taking on the costs: 'Our problem is just this: How to get the benefits of European society - the benefits which have been brought about by an organization of society based on an exaggerated idea of the rights of the individual - and yet retain the African's own structure of society in which the individual is a member of a kind of fellowship?' quoted in T Moloney, Nyerere: The Early Years (Somerset, Boydell and Brewer 2014), 154.

7 'It would be wonderful - and very profitable - if the technology, capital and equipment used productively in rich states could be transferred to poor countries which have not simultaneously evolved a matching set of social, cultural and political institutions': Kay (n 4), 271. Deaton makes a similar point, observing that 'One of the stunning facts about global poverty is how little it would take to fix it, at least if we could magically transfer money into the bank accounts of the world's poor'; instead, in reality 'what surely ought to happen is what happened in the now-rich world, where countries developed in their own way, in their own time, under their own political and economic structures': (n 2), 268, 312.
} 
disparate legal fields all pointing towards conflicting policy goals, so that it is not easy to evaluate whether the legal framework as a whole provides carefully balanced support for economic growth while at the same time upholding widely accepted principles of social justice. When faced with conflicting goals, it becomes difficult to offer a considered response to claims made by entrepreneurs that there is too much 'red tape' obstructing commercial activity, at the same time as fears are being expressed by vulnerable workers that there is too little legal protection against exploitation.

To give an example of such conflicting policy goals, company law is largely designed to enhance flexibility in industrial organization by allowing the parties to enter into contracts of their own choosing, ${ }^{8}$ while employment law prioritizes the goal of safeguarding employment rights by, for example, prohibiting contracts that expose the employee to being overworked or underpaid. ${ }^{9}$ Labour law attempts to protect vulnerable workers with institutional support for the minimum wage, by shoring up the work-wage bargain as the central construct of the contract of employment and by ensuring that workers are not unfairly dismissed thereby defeating their future expectation of employment income. For employment protection to be effective it is necessary to encompass as many workers as possible within its protective fold; but this immediately threatens to destabilize organizational models based on flexibility and arms-length contracting with independent self-employed agents who fall outside the scope of employment protection. Hence the gig economy debates have been conducted from diametrically opposed perspectives: employment protection on the one hand and freedom to choose flexible business structures on the other. ${ }^{10}$

The resulting diversification of legal discourse produces discrete and almost 'hermetically sealed' doctrinal fields ${ }^{11}$ where labour law focuses on protecting workers from exploitation while corporate and financial law prioritize matters related to shareholder value. ${ }^{12}$ This in turn

\footnotetext{
${ }^{8}$ FH Easterbrook and DR Fischel, The Economic Structure of Corporate Law (Harvard University Press 1991).

${ }^{9}$ Eg the UK's Working Time Regulations 1998 and the National Minimum Wage Act 1998.

${ }^{10}$ B Means and JA Seiner, 'Navigating the Uber Economy' (2016) 49 University of California Davis, 1511.

${ }^{11}$ As Anderman argues, 'the endurance of the concept of the business as being solely owned by the employer has hitherto been reinforced by the evolution of a UK company law hermetically sealed off from labour law developments': S Anderman, 'Termination of Employment: Whose Property Rights?' in C Barnard, SF Deakin and GS Morris, eds, The Future of Labour Law: Liber Amicorum Bob Hepple QC (Oxford, Hart 2004), 126.

${ }^{12}$ Notable exceptions, which highlight the value of employees and other stakeholders, include M Moore, Corporate Governance in the Shadow of the State (Oxford, Hart 2013), I L Fannon, Working Within Two Kinds of Capitalism: Corporate Governance and Employee Stakeholding - US and EC Perspectives (Oxford, Hart 2003), MM Blair and MJ Roe, Employees and Corporate Governance (Brookings Institution Press 1999).
} 
leads to a situation where the regulatory framework as a whole adopts divergent labouroriented and capital-oriented approaches implemented independently without meaningful cross-reference to each other. ${ }^{13} \mathrm{~A}$ striking example of this divergence is seen in relation to decision-making in large corporations, which is governed in distinct ways by both fields. Company law vests power in the board of directors, subject to election and monitoring by shareholders, under the aegis of a fiduciary obligation to make decisions in the best interests of the company as a whole. No mention is made in that field of the employer's legal obligation to consult workers when making decisions and to ensure that worker representatives have sufficient information to ensure meaningful consultation. ${ }^{14}$ For its part, labour law accords a prominent role to the legislative framework mandating recognition of trade unions for purposes of collective bargaining and also mandating consultation of employee representatives during business restructuring such as redundancies associated with selling the business or changing the business model. Little if anything is said in this legislation about the overriding duty of directors to promote the best interests of the company, whose interests are depicted in the relevant case law as the interests of its shareholders. ${ }^{15}$ Labour legislation therefore fails to convey realistically the true impact of the worker consultation provisions. This results in a situation where consultation rights may be perceived in labour law studies as an effective avenue for worker participation, whereas the truth is that these rights invariably yield to shareholder primacy when the company's directors are making strategic decisions. This reality may be entirely overlooked if the labour lawyer has limited exposure to the tenets of company law. ${ }^{16}$ In that light it could be said that the strength of

\footnotetext{
${ }^{13}$ The same divide exists between those who advocate for stakeholder capitalism with a role for labour in decision-making (non-contractarians) and those who insist upon shareholder-primacy based on the contractual allocation of decision-making rights (contractarians): 'Contractarians and non-contractarians no longer have much of interest to say to one another; indeed, they barely speak the same language. To shift metaphors, those of us who adhere to the nexus of contracts model pass those who do not like two ships in the night, with only an occasional exchange of broadsides to enliven the proceedings:' SM Bainbridge, 'Community and Statism: A Conservative Contractarian Critique of Progressive Corporate Law Scholarship' (1997) 82 Cornell Law Review $856,860$.

${ }^{14} \mathrm{M}$ Hall, 'Assessing the Information and Consultation of Employees Regulations' (2005) 34 Industrial Law Journal 103.

${ }^{15}$ Greenhalgh v Arderne Cinemas [1946] 1 All ER 512: 'The phrase, "the company as a whole," does not (at any rate in such a case as the present) mean the company as a commercial entity as distinct from the corporators. It means the corporators as a general body. That is to say, you may take the case of an individual hypothetical member and ask whether what is proposed is, in the honest opinion of those who voted in its favour, for that person's benefit.'

${ }^{16}$ For fuller discussion see W Njoya, 'The Problem of Income Inequality: Lord Wedderburn on Fat Cats, Corporate Governance and Workers' (2015) Industrial Law Journal 394.
} 
Lord Wedderburn's longstanding support for independent trade union representatives, in the context of corporate governance reforms designed to reflect workers' concerns in corporate decision-making, was to a significant degree reinforced by the depth of his insight into the inherent weakness of worker consultation principles when viewed in the context of shareholder primacy. ${ }^{17}$ The example of corporate decision-making thus illustrates the benefit to be gained from a closer engagement between labour and company law.

One could perhaps explain the need for divergent doctrinal treatment of what is essentially the same substantive issue, i.e. the legal principles governing the obligations of corporate decision-makers, as the natural result of doctrinal specialization and the desire to avoid regulatory overlap. It is reasonable for each field of regulation to have its own targeted concerns, and so it is not surprising that each doctrinal field remains primarily selfreferential. $^{18}$ The paucity of meaningful engagement between labour-oriented and corporate-oriented fields of study is also unsurprising to the extent that they stand almost as ideological opponents: the goals of each field are held dear, the stakes are correspondingly high, and too close an engagement with the opposing perspective may seem to be at best a betrayal of fundamental values and at worst some kind of Faustian bargain. The difficulty presented by this state of affairs is that while developments in each field continue to be influenced almost exclusively by reference to internal priorities, concerns about social welfare will fail to permeate the efficiency-based principles according to which corporations are governed, leading to a situation where economic growth is perceived to come only at an unacceptable social cost. This then produces a wholesale backlash against capitalism, with too little appreciation of the role it plays in sustaining human progress. ${ }^{19}$ The nexus between

\footnotetext{
${ }^{17}$ Lord Wedderburn's writings on this question include: 'Employees, Partnership and Company Law' (2002) 31 ILJ 99; 'Companies and Employees: Common Law or Social Dimension?' (1993) LQR 220; 'Trust, Corporation and The Worker' (1985) 23 Osgoode Hall Law Journal 203; 'The Legal Development of Corporate Responsibilities: For Whom Will Corporate Managers be Trustees?' in KJ Hopt and G Teubner (eds), Corporate Governance and Directors' Liabilities: Legal, Economic and Sociological Analyses on Corporate Social Responsibility (Berlin: Walter de Gruyter 1985); 'The Social Responsibilities of Companies' (1982) 15 Melbourne University Law Review 1.

18 Being self-referential does not imply that they must be closed to external influence: distinct fields can be understood as 'autonomous' and internally coherent, while remaining 'interdependent' and 'cognitively open' to external influence: S Deakin, 'Legal Evolution: Integrating Economic and Systemic Approaches' (2011) 7 Review of Law and Economics 659, 674.

${ }^{19}$ The backlash is global: 'The divergence between the fortunes of labor (Main Street) and capital (Wall Street) has left many on Main Street confused and bitter. In the view of many Americans, company profits seem to come at the expense of social well-being. Thus, it is not surprising that the concept of "stakeholder" capitalism - a kinder, gentler corporation taking increased social "responsibility" for its many constituents - is in vogue': P Fagan and MC Jensen, 'Capitalism isn't Broken' Wall Street Journal, March 29, 1996, page A-10.
} 
capitalism and economic wellbeing becomes particularly compelling if we adopt the broad frame of inquiry constructed by Angus Deaton, encompassing 'material wellbeing, such as income and wealth; physical and psychological wellbeing, represented by health and happiness; and education and the ability to participate in civil society through democracy and the rule of law'. ${ }^{20}$ All this is central to an evaluation of the social cost of capitalism.

A more measured approach in evaluating the two faces of capitalism therefore requires a close examination of the interplay between a wide range of legal principles regulating the labour-capital exchange, with cross-references across doctrinal boundaries, in order to evaluate the role of law in capitalist society. On that basis this discussion highlights the social welfare function of large companies as an intrinsic part of the company's internal organizational drive for productivity and growth. Hence the 'company welfare state' ${ }^{21}$ is depicted here as a construct in which social welfare is bound up with the company's own productive goals rather than being inimical to those goals. This in turn enables a more complete evaluation of the larger role played by the government-funded welfare state in providing income security. The analysis is completed by questioning the wisdom of linking social welfare to economic equality, particularly when that link is presented as a justification for law reform in the fields of employment law and corporate governance. At present, with little meaningful engagement between the opposing sides in the free market versus employment protection debates, and insufficient reflection on the interplay between progress and inequality, it is difficult to formulate realistic and sustainable solutions to pressing social and economic concerns. By following Deaton's approach, both sides of the 'endless dance between progress and inequality' are given due attention, thereby opening new lines of inquiry into the social welfare effects of free markets and casting law reform debates in a fresh light. ${ }^{22}$

For legal scholars, a clear picture of these interconnections is particularly important in addressing two major problems with which this discussion is concerned: first, rising inequality and second, the increasing fiscal burden on the welfare state. Large corporations are strongly implicated in both problems, with data suggesting that the financialization of corporate

\footnotetext{
20 (n 2), 24.

${ }^{21} \mathrm{~F}$ Field, Inequality in Britain: Freedom, Welfare and the State (London, Fontana 1981) chapter 8, 136 et seq.

22 Deaton (n 2), xiii; for a similar approach in political philosophy see J Tomasi, Free Market Fairness (Princeton University Press 2012).
} 
governance is one of the causal factors in increasing the gap between senior managers and minimum-wage workers ${ }^{23}$ and accusations that large corporations avoid paying tax and social security contributions. ${ }^{24}$ But even if it is conceded that large corporations are strongly implicated in bringing great misery to the modern world, at the same time they are also responsible for bringing about the great prosperity enjoyed in our time. ${ }^{25}$ Both stories are important. This discussion therefore straddles the ideological boundaries that too often inhibit open debate, with the aim of juxtaposing the two faces of capitalism: the inspirational face of innovation, productivity, growth and prosperity, ${ }^{26}$ and the darker face where financial scandals, systemic failures, institutionalised fraud, and rising inequality raise urgent social welfare concerns.

Although the discussion draws primarily upon the law in the UK, these insights also apply to the functioning of capitalist institutions in emerging markets in so far as they explain some of the reasons why the predominant legal framework in advanced economies has adopted its current form. This in turn sheds light on the prospects of success for poor countries wishing to realize the benefits of capitalism, namely vibrant economies and an exponential rise in the standard of living. While the complexity of economic systems precludes a simplistic attribution of success or failure to any single market institution, it is nevertheless helpful for those concerned with economic development to understand better the role played by the regulation of work in large firms.

The rest of the discussion proceeds as follows. Part two introduces one of the main reasons why capitalism often comes under fire, namely the apparent weakness of law and regulation when faced with corporate scandals. Part three critically evaluates the scope of regulatory

\footnotetext{
${ }^{23}$ T Piketty, Capital in the Twenty First Century (Harvard University Press 2014).

24 'Amazon paid just $£ 15 \mathrm{~m}$ in tax on European revenues of $£ 19.5 b n$ ' The Guardian 10 August 2017; $\mathrm{H}$ Konkolewsky, 'Does Uber signal the end of social security?' https://iloblog.org/2016/07/28/does-uber-signalthe-end-of-social-security/

${ }^{25}$ C Mayer, Firm Commitment: Why the Corporation is Failing Us and How to Restore Trust in It (Oxford University Press 2013) describing the corporation as a 'remarkable institution that has created more prosperity and misery than could ever have been imagined', 1.

26 'Today, one person escapes extreme poverty every second, thanks to better economic systems, improved knowledge, and cheaper technology in most areas of the world. In just the past year, more than 32 million people have escaped poverty, bringing the percentage of the world population living under the international extreme poverty line from 9.2 percent to 8.7 percent. The United Nations projects that another 79 million people will climb above the extreme poverty line by 2020': C Hughes, 'Massive Reduction in Global Poverty Might Be the Most Important Development in the World', June 12, 2017 available at https://economics21.org/html/massivereduction-global-poverty-might-be-most-important-development-world-2387.html
} 
intervention in market transactions, before focusing in part four on the private law framework underpinning free market capitalism. It is significant that the ideals of private property and freedom of contract have a comparatively weak presence in societies that have been left behind by the industrial revolution and the digital economy. This suggests that the importance of private law principles in facilitating market transactions has tended to be overlooked by those concerned with socio-economic progress, an oversight which this article seeks to redress. To that end, part five advocates for a more careful treatment of the role played by corporate law and regulation, focusing not only on wealth distribution but also on wealth creation. Part six identifies how consumption patterns and other measures of economic wellbeing improve upon the narrow compass of income distribution, thus offering a more realistic overview of the social welfare effects of capitalism. The intuition is that an overemphasis on equality at the expense of innovation and growth may be a worthwhile trade-off in some types of economies but not others, and should therefore be treated with caution. Before the discussion concludes, part seven applies these insights to the challenge of reconstructing the welfare state as the gig economy threatens to destabilize the predominant juridical form of the contract of employment.

\section{Corporate scandals and the boundaries of illegality}

Large corporations offer employment to millions of workers around the globe, but the endemic problem of corporate scandals too often spells financial disaster for those workers. In a notable case recently investigated by the UK's Serious Fraud Office, the collapse in 2016 of the iconic department store BHS triggered the loss of 11,000 jobs and left a $f 571$ million pension deficit affecting 20,000 workers. In other recent examples, widespread fraud in setting up customer accounts at the venerable American bank Wells Fargo led to the dismissal of thousands of its lower-paid employees between 2011 and 2016, while on the other side of the globe the discovery of a $f 5$ billion accounting scandal at the South African firm Steinhoff International threatened to trigger the demise of Poundland from the British high street in December 2017, putting thousands of jobs at risk. The public debate is ongoing as to how law should respond, and in particular whether there should be greater scope to hold the executive 
officers personally liable when the company collapses on their watch. ${ }^{27}$ This part of the discussion offers an overview of some of the challenges faced by law in the wake of such scandals, setting the stage for the subsequent discussion in part three about the role of law in facilitating and constraining corporate activity.

It is appropriate to begin by observing that following the insolvency or collapse of large companies thousands of ordinary workers lose their jobs and their expectation of future income, while the corporation's controllers often move on to the next opportunity with a bonus and a promotion, or perhaps retire with a so-called golden parachute. ${ }^{28}$ The assetpartitioning function of company law separates the personal fortunes of shareholdercontrollers from the assets and liabilities of the company as a separate legal entity, thus shielding the directors and other company executives from financial disaster in the absence of fraud or other illegality. The ability of wealthy controllers at the helm of the company quite lawfully to insulate themselves from the financial risks to which their employees remain fully exposed strikes many observers as unconscionable and thereby threatens to undermine public confidence in the principle of limited liability which enables corporate entities to flourish. There are further concerns regarding the capacity of the public purse to meet all the social welfare claims that displaced workers are entitled to make including compensation for their lost wages and pensions, as the collapse of a single large company often gives rise to significant costs in the form of government bail-outs that may amount to millions of pounds. ${ }^{29}$

One of the difficulties in attributing legal liability in these situations lies in distinguishing between unlawful activity and those transactions that, although lawful, nevertheless incur critical opprobrium. ${ }^{30}$ It has been established since Salomon that while a director may have

\footnotetext{
${ }^{27}$ M Croser, 'Carillion collapse shows need for company reform', The Guardian January 22, 2018, arguing that there is a need to reform the Companies Act to ensure better outcomes for employees and other stakeholders. ${ }^{28}$ The BHS case is typical in that respect: 'Many of those closest to the decisions that led to the collapse of BHS have walked away greatly enriched despite the company's failure': BHS: First Report (n 3), par. 7. The Report concludes: 'The truth is that a large proportion of those who have got rich or richer off the back of BHS are to blame. Sir Philip Green, Dominic Chappell and their respective directors, advisers and hangers-on are all culpable. The tragedy is that those who have lost out are the ordinary employees and pensioners. This is the unacceptable face of capitalism': par. 168.

29 'Carillion collapse: Ministers under pressure over taxpayer bill after admitting to unknown 'insolvency costs', The Independent, January 16, 2018; Carillion collapse leaves 30,000 businesses losing out on up to f1bn,' The Telegraph, January 16, 2018.

${ }^{30}$ There is, of course, a normative debate concerning the appropriate boundaries of the law, but the point remains true that regardless of where the boundary lies there is still an analytical distinction between legal liability and social disapproval of corporate conduct.
} 
behaved in a manner that is widely considered to be shameful, that conduct may well amount to a breach of 'moral duty' but it will not, on that basis only, be in breach of the law. ${ }^{31}$ While the issue in that case concerned the validity of incorporation, the ruling in Salomon continues to capture the legal imagination for its exegesis on the relevance of moral probity to the operation of company law. There is enduring fascination with the 'essentially ethical basis of the decision about whether Aron Salomon acted with appropriate decency to people with whom he did business, ${ }^{32}$ first by incorporating his business without alerting his creditors as to the full implications (incorporation is a matter of public record so his creditors could and should have looked to their own welfare ${ }^{33}$ ) and then compounding his sins by taking out secured debentures giving legal priority to his personal financial claims on the collapsed business and thereby defeating the claims of his unsecured creditors (also perfectly lawful as the insolvency was not reasonably foreseeable at the time of the transaction ${ }^{34}$ ).

Drawing analytical distinctions between lawful and unlawful conduct is not the only challenge; the relevant evidence must then be found to prove the existence of fraud or other illegality to the required standard of civil or criminal proof. To illustrate the difficulties involved, it has been estimated that approximately two thirds of all frauds in the US remain undetected. ${ }^{35}$ This includes matters that are inherently difficult to identify or prove such as 'Iying about the future' for instance when raising capital based on proposed new projects. ${ }^{36}$

\footnotetext{
31 'Whatever may be the moral duty of a limited company and its shareholders, when the trade of the company is not thriving, the law does not lay any obligation upon them to warn those members of the public who deal with them on credit that they run the risk of not being paid': Salomon v Salomon \& Co [1897] AC 22, 40 (Lord Watson). As Lord Halsbury said, 'Whether such a result be right or wrong, politic or impolitic, I say, with the utmost deference to the learned judges, that we have nothing to do with that question if this company has been duly constituted by law; and, whatever may be the motives of those who constitute it, I must decline to insert into that Act of Parliament limitations which are not to be found there', 34.

${ }^{32}$ AC Hutchinson and I Langlois, 'Salomon Redux: The Moralities of Business' (2012) 35 Seattle University Law Review 1109. See also P Ireland, 'Limited Liability, Shareholder Rights and the Problem of Corporate Irresponsibility' (2010) 34 Cambridge Journal of Economics 837 for an argument that the law 'institutionalizes' corporate irresponsibility.

${ }^{33}$ Said Lord Macnaghten: 'The unsecured creditors of A. Salomon and Company, Limited, may be entitled to sympathy, but they have only themselves to blame for their misfortunes' Salomon v Salomon (n 31) 53.

${ }^{34}$ Lord Macnaghten observed that Salomon's primary motive was a desire to expand his business and provide for his family, but unfortunately he soon encountered a market downturn: 'My Lords, I cannot help thinking that the appellant, Aron Salomon, has been dealt with somewhat hardly in this case...The company had a brief career: it fell upon evil days. Shortly after it was started there seems to have come a period of great depression in the boot and shoe trade' and Salomon's efforts shore up his company failed: 'Mr. Salomon seems to have done what he could [but] the temporary relief only hastened ruin' Salomon v Salomon (n 31), 47, 49.

35 A Dyck, A Morse and L Zingales, 'How Pervasive is Corporate Fraud?' (April 2017) available at http://www.law.nyu.edu/sites/default/files/upload_documents/Adair\%20Morse\%20How\%20Pervasive\%20is\% 20Corporate\%20Fraud.pdf.

${ }^{36} \mathrm{Ibid}, 4$.
} 
The estimated cost of all fraud in US publicly traded firms amounts to 'between $\$ 180$ and $\$ 360$ billion a year' including not only the cost of detected fraud but also the residual loss in enterprise value from frauds that go undetected as well as losses borne by all firms in the relevant industry, not just the individual firm that perpetrated the fraud. ${ }^{37}$ In the aftermath of the collapse of a large corporate employer, there is a further challenge in establishing a causal link between such fraud and the subsequent losses sustained by creditors or employees. Again, it has been well established since Salomon that an allegation of fraud requires something more than a 'loose and general' advertence to the collapse of the company plus the fact that the controller appears to have creamed off all the profit before bailing out leaving the company's coffers empty and the creditors unsatisfied. ${ }^{38}$

Fraudulent intent to deceive, as distinct from an unfortunate downturn in the market such as that which befell Mr Salomon, may be difficult to establish following insolvency. This was a complicating factor in the BHS collapse, as sales were struggling and there were industry-wide workplace pensions challenges. ${ }^{39}$ As in Salomon's case, there was a public perception that it was morally wrong for the controlling Green family to retain their financial gains following a catastrophe that defeated innocent stakeholder claims; but in the absence of fraud it was not unlawful for the Greens to increase their personal wealth by drawing upon the profits of BHS (it is not unlawful to be a wealthy capitalist). Such conduct may potentially amount to a breach of trust: Philip Green was criticised for profiting at the expense of the company's own sustainability and success, ${ }^{40}$ a serious allegation given that conduct undermining the long

\footnotetext{
${ }^{37}$ Ibid, 34 .

38 'The allegations of the company...were meant to convey a charge of fraud; and it is unfortunate that they are framed in such loose and general terms. A relevant charge of fraud ought to disclose facts necessitating the inference that a fraud was perpetrated upon some person specified': Salomon $v$ Salomon (n 31), 35.

39 'The reason BHS has gone bust is no mystery. Shoppers' tastes have shifted and fusty old BHS hasn't kept up': B Chu, 'BHS: What's the real story behind the collapse of the 88-year-old department store?' The Independent, $25^{\text {th }}$ April 2016. The pensions regulator observed: 'we recognise that the emergence and increase in the size of the deficit of the [pension] schemes was in part due to economic and demographic factors which have affected nearly all [Defined Benefit pensions] schemes': The Pensions Regulator, Regulatory Intervention Report: issued under section 89 of the Pensions Act 2004 in relation to the BHS pension schemes (June 2017), 30.

40 'the Green family became incredibly wealthy, partly on the back of BHS, but in doing so reduced the capacity of the company to invest and succeed': BHS: First Report (n 3), par 3. This was achieved by 'the Green family paying itself dividends far in excess of company profits' (par 10) and failing to 'invest enough to maintain the value of the company' (par 14) although in Philip Green's view, shared by some other shareholders, 'the company was profitable and the dividends were conservative' (par 11).
} 
term success of the company is a fundamental breach of a director's fiduciary duties. ${ }^{41}$ For publicly traded companies, this statutory duty is supplemented by a Corporate Governance Code setting out institutional best-practice guidelines with which companies must 'comply or explain'. ${ }^{42}$

Yet ascertaining precise grounds of liability in these circumstances may still prove difficult; in the end Philip Green was issued with a Warning Notice under the Pensions Act, ${ }^{43}$ on the basis that he had a personal liability to make a financial contribution to the scheme. ${ }^{44}$ This liability did not arise simply from selling the company to a buyer who turned out to have no feasible means of redressing ongoing concerns regarding the pensions deficit. Rather, Sir Philip's alleged failures, as previously highlighted by the parliamentary inquiry into the BHS collapse, lay primarily in doing nothing, or nothing sufficient, to bolster the pension schemes while he was at the helm despite numerous opportunities to do so. The inquiry took the view that he should not escape his 'moral duty to act' by the simple expedient of selling the company. ${ }^{45}$ This reasoning is to a degree reflected in the broad scope of legal liability of former directors for breaches of fiduciary duty or wrongful trading that occurred before they resigned from their post. ${ }^{46}$ However, although Sir Philip ultimately paid $£ 363$ million to the pensions regulator to settle the matter he insisted that his ex post, and indeed ex gratia, contribution

\footnotetext{
${ }^{41}$ s.172 of the Companies Act 2006: 'A director of a company must act in the way he considers, in good faith, would be most likely to promote the success of the company for the benefit of its members as a whole'; for a helpful discussion see Mayer ( $\mathrm{n} 25)$.

${ }^{42}$ The Code, published by the Financial Reporting Council, is not legally binding but any non-compliance must be explained. The BHS Report found 'a paucity of challenge and oversight which allowed Sir Philip to run it as a family empire' conduct which, if it occurred in a public company, would clearly violate core principles of the Code: BHS: First Report (n 3).

${ }^{43}$ The Warning Notice alleged that 'the main purpose of the sale was to postpone BHS' insolvency to prevent a liability to the schemes falling due while it was part of the [Green family] group of companies' Regulatory Intervention Report (n 39), 29; accordingly he was issued with a Contribution Notice requiring him to make a cash payment to the pension scheme ( $n 39), 22$.

${ }^{44}$ The matter was eventually settled: 'the settlement reached was expressly on the basis of no admission of liability on the part of Sir Philip Green' (Ibid, 2). The company's new owners were later convicted under $s 72$ of the Pensions Act: 'The former owner of BHS, Dominic Chappell, has been ordered to pay a $f 50,000$ fine and $£ 37,000$ court costs for failing to disclose vital details to the pensions watchdog as part of its investigation into the collapse of the high street chain' The Guardian, 23 February 2018.

${ }^{45}$ The Parliamentary Select Committee was concerned not just with 'the growth of BHS's pension deficit' but also with 'the repeated failure of Sir Philip Green and his directors to take opportunities to resolve it'; the Report concluded that 'Sir Philip owes it to the BHS pensioners to find a resolution urgently. This will undoubtedly require him to make a large financial contribution. He has a moral duty to act, a duty which he acknowledges': BHS: First Report (n 3), par. 173.

${ }^{46}$ s. 170 Companies Act 2006: 'The general duties specified in sections 171 to 177 are owed by a director of a company to the company...those duties apply to a former director as to a director, subject to any necessary adaptations'.
} 
to the BHS pension pot was prompted not by the strength of the legal case against him but by his desire to 'behave like a gentleman' ${ }^{47}$

In these circumstances, it is not surprising that the legal framework regulating financial conduct does not inspire confidence. The widespread public sense that more can and ought to be done by the legal framework to establish liability on the part of specific individuals is understandable. Yet more law is not always the answer; in the context of workplace pensions tighter regulations may well help to make these schemes more secure but only at the risk of reducing the scope and effectiveness of available coverage. ${ }^{48}$ As in other financial contexts, this has raised concerns that 'the response throughout history to financial crises is to seek more regulation' ${ }^{49}$ which in turn throws up a new set of long-term problems as was seen after the last global financial crisis. ${ }^{50}$ Short-term patches based on more stringent regulation do not always resolve complex problems. ${ }^{51}$ For instance, in the determination to claw back money from former executives of failed companies or current executives who are guilty of being paid 'too much,' new regulations are periodically introduced that are promptly side-stepped by highly adept 'transaction engineers' ${ }^{52}$ using clever strategies and devices that will in time

\footnotetext{
47 J Phillips, 'Green Defends BHS Record: “I behaved like a gentleman”' Professional Pensions, 16 April 2008 available at https://www.professionalpensions.com/professional-pensions/news/3030249/green-defends-bhsrecord-i-behaved-like-a-gentleman. Frank Field MP, who chaired the parliamentary inquiry, might beg to differ; in his view 'Sir Philip Green stripped BHS bare and then left it for dead, with contemptuous disregard for the pensioners': S Butler, 'Green's 'main purpose' in BHS sale was to avoid pension liability, says watchdog' The Guardian, 27 June 2017.

48 'the UK government's response to "events", such as Maxwell, Equitable Life, BHS - fuelled by the reporting of such events in the media, is to apply more and more regulation across the whole sector. This may mean that members of pension schemes are better protected but the decline of [defined benefit pensions] has shown that such protection comes at a price - far fewer new and young employees covered by such benefits. Overregulation also makes pensions more complex and harder for ordinary people to understand': B Scott, Chair Association of Consulting Actuaries (ACA) available at http://www.actuarialpost.co.uk/article/lets-hear-moreabout-pension-good-news-says-aca-chair-13462.htm

${ }^{49}$ Mayer (n 25), 58.

50 'the political pressure to be seen to act in the face of failure is overwhelming and, as night follows day, we will see a significant extension and tightening of regulations that will undermine the operation of financial markets for years to come': ibid, 59 .

51 'What is wrong with responding to financial crises with strengthened regulation? Numerous things: for one, the horse has bolted. Those people who were lucky enough to escape before the crash have made their fortunes; those who did not have suffered their losses...Second, regulation is pro-cyclical. Just as a steady relaxation of regulation during the first part of this decade encouraged increased investment and asset price rises, thereby fuelling the bubble, so too a tightening of regulation will now raise the cost of capital, discourage investment, and exacerbate the downturn': ibid, 59.

${ }^{52}$ As said in the aftermath of new financial market regulations in the US, 'we await the next alter-ego-based innovation from Wall Street's transaction engineers with an incomplete menu of defensive responses': WW Bratton and AJ Levitin, 'A Transactional Genealogy of Scandal: From Michael Milken to Enron to Goldman Sachs' (2013) Southern California Law Review 783, 784.
} 
trigger the next scandal. As Kevin Murphy observes in his study of historical attempts to regulate executive pay, successive regulatory reforms designed to close the corporate wage cap have seen companies 'circumventing or adapting to the reforms, usually in ways that increased pay levels and produced other unintended (and typically unproductive) consequences. ${ }^{53}$ Regulators attempting to outsmart corporate executives in the hope of beating them at their own game have so far not been successful.

Hence the efforts to achieve fair outcomes for all the corporation's stakeholders would be better off to begin by acknowledging that the legal framework offers enormous scope for flexibility in corporate organization and management, which in turn militates against traditional regulatory approaches. Furthermore, the examples discussed here show that the distinction between lawful and unlawful activities does not necessarily correspond to public expectations of basic fairness and morality-based ethics, a lesson that has historically been reiterated by the courts in the long line of unsuccessful attempts to 'pierce the veil' and hold companies liable to pay the debts of associated entities that are, in law, separate legal persons. In this context considerations of 'justice' are not, by themselves, a sufficient ground giving courts jurisdiction to set aside lawful commercial arrangements. ${ }^{54}$ The ideology of shareholder primacy and the norms associated with efficiency and profit-maximisation have therefore proved in common law jurisdictions to be remarkably impervious to justice-based anti-capitalist arguments. ${ }^{55}$ The law continues to operate broadly within a framework of facilitative default rules, tax incentives and voluntary codes of conduct. ${ }^{56}$ The UK

\footnotetext{
${ }^{53}$ K Murphy, 'Executive Compensation: Where We Are, and How We Got There' in G Constantinides, M Harris and RM Stulz (eds), Handbook of the Economics of Finance (Amsterdam, Elsevier Science North Holland 2013), 211, 214.

54 In Adams v Cape Industries [1990] Ch 433 it was argued, unsuccessfully, that an award of damages by an American court should be enforced in the UK against the parent company (a separate legal entity) on the basis of 'natural justice' or 'substantial justice'. Further progress in 'lifting the veil' has resorted to the sphere of tort law, with a broader interpretation of the duty of care and vicarious liability (Chandler v Cape Plc [2012) EWCA Civ 525), and the law governing constructive trusts (Prest v Petrodel Resources Ltd [2013] UKSC 34).

${ }^{55} \mathrm{H}$ Hansmann and R Kraakman, 'The end of history for corporate law' (2001) 89 Georgetown Law Journal 439; WT Allen, 'Contracts and Communities in Corporation Law' (1993) 50 Washington \& Lee Law Review 1395. Attempts to reform company law 'from within' have met with limited success: P Ireland, 'Corporate Governance, Stakeholding, and the Company: Towards a less Degenerate Capitalism?' (1996) 23 Journal of Law and Society 287.

${ }^{56}$ This still reflects the future outlook: 'SOX's [Sarbanes-Oxley's post-crisis securities regulation in the US] corporate governance provisions should be stripped of their mandatory force and rendered optional. Other nations, such as the members of the European Union who have been revising their corporation codes, would be well advised to avoid Congress' policy blunder [in displacing 'disclosure requirements' with 'explicit legislative directives']': R Romano, 'The Sarbanes-Oxley Act and the Making of Quack Corporate Governance' (2005) 114 Yale Law Journal 1521, 1529.
} 
Government's latest corporate governance proposals may appear to buck this trend, for instance by promising to do more to tackle fat cat company executives and to prompt directors to engage more effectively with the company's stakeholders, but these proposals can hardly be described as revolutionary since they are intended to update rather than overhaul the existing regulations. ${ }^{57}$ Against that background the next part of the discussion examines in more detail the role that ought to be played by law in responding to these concerns.

\section{Scope of regulatory intervention}

The problem of corporate mismanagement seems at first sight to call for a more proactive regulatory approach, for example by anticipating and forestalling egregious cases of fraud, rather than belatedly introducing ad hoc regulations to address such scandals after the event. The idea behind being more proactive would be to specify in advance the activities that would be wrongful or fraudulent should they occur. An example of this approach is seen in the Insolvency Act which attempts to capture not only cases of carrying on business while insolvent with intent to defraud creditors or for any fraudulent purpose under s. 213, but also cases where although not insolvent, the directors carried on trading when they ought reasonably to have foreseen the likelihood of going insolvent in the near future. ${ }^{58}$ But the difficulty with prohibiting activities that are probably going to end in disaster is that many business activities are inherently risky. ${ }^{59}$ Prohibited activities must therefore be defined with an eye to the desirability of encouraging businesses to undertake the risks of operating in fluctuating markets.

\footnotetext{
57 'The aim of the green paper consultation was to consider what changes might be appropriate in the corporate governance regime to help ensure that we improve business performance and have an economy that works for everyone': Department for Business, Energy and Industrial Strategy, Corporate Governance Reform: The Government Response to the Green Paper Consultation, August 2017, 2, available at https://beisgovuk.citizenspace.com/strategy/corporate-governance-reform/

58 The Insolvency Act 1986 s. 214 imposes liability on directors or former directors of insolvent companies if 'at some time before the commencement of the winding up of the company, that person knew or ought to have concluded that there was no reasonable prospect that the company would avoid going into insolvent liquidation'.

${ }^{59}$ These risks arise from factors that are difficult to legislate for: 'for many firms, a high probability of failure largely reflects idiosyncratic risk, with distress occurring regardless of the condition of the economy. Such failures can stem from a lack of innovation, competitive pressures, industry maturity, idiosyncratic shocks to operations, or decreased product demand': M Ogneva, JD Piotroski and AA Zakolyukina, 'Accounting Fundamentals and Systematic Risk: Corporate Failure over the Business Cycle' (2017) University of Chicago Booth School of Business Working Paper No. 14-31, 1.
} 
This then is the challenge in regulating market transactions. Viewed from an ex ante standpoint facilitating such transactions can lead to either good or bad public welfare outcomes and it is not straightforward to issue pre-determined declarations on the precise types of transactions that ought to be encouraged or forbidden. To draw once again from the BHS saga, selling a company for $€ 1$ or some other nominal sum may appear suspicious especially when the buyers are men with doubtful track records, ${ }^{60}$ but such a sale transaction in relation to a struggling company is not in itself such conclusive evidence of wrongdoing that it ought to be prohibited in all cases. On the contrary it may be beneficial to encourage such a sale where the buyer promises to rescue a failing company and thereby secure the employees' jobs as happened when various attempts were made to rescue Rover, the ailing British car manufacturer. ${ }^{61}$ In the interests of facilitating corporate rescues it could be argued that the legal framework ought not only to permit, but indeed to encourage, companies to be bought and sold at market prices and even restructured to meet shareholder priorities where this would incentivize a further investment of new capital by shareholders. After all, if the company fails then all the jobs will be lost. Moreover, shares are intended to be easily and speedily transferable in order to facilitate vibrant stock markets, and following the transfer of shares the transferor is in principle off the hook for any legal liability subsequently incurred by the company. On the face of it the whole point of company law is to ensure that the shareholders' personal assets cannot be called upon to satisfy the company's liabilities, and while it is true that in some situations there may be statutory power to pursue the directors or shareholders personally this generally depends on evidence of fraud or other illegality.

Another regulatory challenge in responding to corporate scandals arises when the events preceding the disaster are already common knowledge among the firm's employees and managers, ${ }^{62}$ and perhaps even revealed to the financial press by whistle-blowers long before

\footnotetext{
${ }^{60}$ Having between them an extensive personal involvement with previous insolvencies and no feasible means of rescuing BHS: 'It was clear that Chappell's team was woefully short of the requisite experience and expertise, notably lacking the credible senior retailer on whom Sir Philip once insisted. They could offer no equity and had no means of raising funds on a sustainable basis' BHS: First Report (n 3), par 112.

${ }^{61}$ C Villiers, 'The Rover Case (1) The Sale of Rover Cars by BMW-the Role of the Works Council' (2000) 29 Industrial Law Journal 386; J Armour and S Deakin, 'The Rover Case (2)-Bargaining in the Shadow of TUPE' (2000) 29 Industrial Law Journal 395.

62 'Carillion's financial problems have been well-known in the city and no doubt with senior civil servants for over a year': Croser (n 27).
} 
the volcano finally erupts. ${ }^{63}$ The difficulty here is that if the impression has plausibly been created that the activity is nothing secret and therefore presumably above board, then after the fact it may be questioned whether investors or other stakeholders with full knowledge of all the material facts can credibly claim to have been misled or deceived. ${ }^{64}$ In the ensuing chaos there may not be sufficient evidence of any precise wrongdoing, particularly in situations where the managers and senior executives were either privy to the activity that triggered the collapse or at any rate turned a wilful blind eye to what was going on. ${ }^{65}$ There have been suggestions that financial regulators who are inclined to see their role as that of facilitating fast-changing capital markets may sometimes regard the shortcuts and unethical stratagems of ambitious young traders as simply part of the culture. ${ }^{66}$ In the Wells Fargo example, the bank was actually 'famous' for the cross-selling practices that quite predictably incentivised the fraud. ${ }^{67}$ Corporate collapses are in that sense systemic and cyclical, more accurately viewed as an endemic feature of capitalist market economies than as surprising or exceptional occurrences. The challenge for regulators is that there is no straightforward or rational way to explain how an open and commercially widespread approach to doing the very activities envisaged and indeed encouraged by law can possibly be 'wrongful' in the absence of evidence of fraud or breach of trust.

This raises a more fundamental question of greater urgency for many analysts of capitalism, and indeed for some of the judges who find their hands tied in cases where the company's

\footnotetext{
${ }^{63}$ Whistle-blowers including employees and journalists are more instrumental in exposing corporate fraud than the lawyers, auditors, investors and non-executive directors who are officially deemed to fulfil the monitoring function in the company: A Dyck, A Morse and L Zingales, 'Who Blows the Whistle on Corporate Fraud?' (2010) 65 Journal of Finance 2213.

${ }^{64}$ As was said by Lord Watson in Salomon, in relation to the conduct of Mr Salomon that was alleged to be fraudulent, 'it is clear that if so, though he may have been its originator and the only person who took benefit from it, he could not have done any one of those things, which taken together are said to constitute his fraud, without the consent and privity of the other shareholders' (n 31), 39.

${ }^{65}$ News reports exposing the fraud at Wells Fargo, including cases where customers had launched litigation, stretched back for up to 10 years; Bernie Madoff infamously got a 150 year prison sentence for fraud in respect of activities that had been going on for decades and into which, he argued, his investors had simply preferred not to inquire too closely as they were happy with the returns he offered on their investments even though those returns were at the very least 'highly suspicious': C Bernard and PP Boyle, 'Mr. Madoff's Amazing Returns: An Analysis of the Split-Strike Conversion Strategy' (2009) 17 Journal of Derivatives 62.

${ }^{66}$ In essence, corruption and fraud are perceived by some within the financial services sector and even by some regulators as quite normal: JS Nelson, 'The Corruption Norm' (2017) Journal of Management Inquiry 280.

${ }^{67}$ R Prentice, 'Wells Fargo Goes Far to Cheat Customers, and It Was Predictable' University of Texas News, September 19, 2016 available at https://news.utexas.edu/2016/09/19/it-was-predictable-that-wells-fargocheated-customers.
} 
directors have done something 'scandalous' but not unlawful, ${ }^{68}$ in that context it could be argued that the law itself, as currently formulated and independent of questions concerning fraud or other illegality, is inherently flawed in so far as it supports the existing framework of capitalism. ${ }^{69}$ Such disillusionment with the ability of law to reform the functioning of capitalist institutions with which law itself is complicit explains the shift in the policy debates away from legal solutions and more towards the sphere of moral philosophy where considerations of social justice can more explicitly inform governance reforms. This shift is reflected in Colin Mayer's call for a closer consideration of the meaning of trust in market institutions, for directors and managers to look beyond an exclusive focus on maximizing profits, and for policy makers to end their preoccupation with asking what can be done by governments to design progressively stricter codes of corporate governance in the futile hope that this regulatory method that has repeatedly failed in the past will suddenly produce the anticipated results. ${ }^{70}$ Mayer suggests that rather than looking to governments and regulators to fix corporate governance problems, the solution lies in a reimagination of the function of corporations and a reinterpretation of how they pursue their goals.

Mayer's proposals recall the fact that the most successful corporations are never those whose founders dreamed only about profits but rather those who sought to create valuable goods and services for the public; hence the overriding function of the corporation in his view is 'to make, develop and deliver things and to service people, communities and nations. ${ }^{171}$ In that sense his perspective seems at first sight to be diametrically opposed to that of Milton Friedman, who is widely derided for saying that the social responsibility of corporations is to maximize their profits. ${ }^{72}$ But on closer inspection it becomes clear that the two perspectives

\footnotetext{
${ }^{68}$ As expressed in Salomon in relation to floating charges that are perfectly lawful but also cause great mischief, the law sometimes places a higher premium on the convenience of commercial transactions: 'For such a catastrophe as has occurred in this case some would blame the law that allows the creation of a floating charge. But a floating charge is too convenient a form of security to be lightly abolished. I have long thought, and I believe some of your Lordships also think, that the ordinary trade creditors of a trading company ought to have a preferential claim on the assets in liquidation in respect of debts incurred within a certain limited time before the winding-up. But that is not the law at present. Everybody knows that when there is a winding-up debentureholders generally step in and sweep off everything; and a great scandal it is' (n 31), 53 (Lord Macnaghten).

${ }^{69}$ See Ireland (n 55).

70 'We should call a halt to this failed experiment in political economy and look elsewhere for alternative approaches to the management of $21^{\text {st }}$ century commercial affairs': Mayer (n 25), 253.

71 lbid, 4.

72 'there is one and only one social responsibility of business - to use its resources and engage in activities designed to increase its profits so long as it stays within the rules of the game, which is to say, engages in open
} 
share a similar focus on the essential purpose and function of the corporation. Friedman was no more interested than Mayer in profit-making for its own sake; instead Friedman's welfaremaximizing approach emphasized the potential of market institutions such as the corporation to enhance prosperity and freedom for the vast majority of people. The cogency of Friedman's vision is borne out by the experience of Tanzania referred to in the Introduction, where long decades of socialist decline were eventually replaced by efforts to support the operation of open markets in a move that has similarly commended itself across the third world with promising results: 'This move to market-oriented, open economic systems has initiated a process that is putting 1.2 billion Third World workers into world-wide product and labor markets over the next generation. ${ }^{173}$ This trend has increased in recent years as the digital age makes global markets even more accessible to ordinary traders. ${ }^{74}$

While no reasonable person would suppose that open markets are perfectly functional, or even less that they are perfectly competitive, liberal thinkers in the classical tradition argue that market outcomes are often superior to legislative co-ordination of commercial transactions. It is undeniable that some people when left free to externalize their costs onto society are probably going to be tempted to do just that if they lack a moral compass or social conscience, but the risk with legislative intervention, as adverted to above, is that the attempt to prevent such externalities by using law as a proxy for market ordering risks creating even bigger externalities. ${ }^{75}$ The lesson that can be drawn from these different perspectives is that regulation, even when it has undoubtedly admirable goals of social justice, must take sufficient account of the longer-term implications. ${ }^{76}$ Otherwise there is a risk of inadvertently

\footnotetext{
and free competition, without deception or fraud. Similarly, the "social responsibility" of labor leaders is to serve the interests of the members of their unions:' Friedman ( 4 ), 133.

${ }^{73}$ Fagan and Jensen (n 19), A10.

74 'With relatively modern technology, experience indicates that these Third World workers can produce from $85 \%$ to $100 \%$ of the output of their Western compatriots': ibid.

75 'the creation of one externality then leads to the demand to "solve" that by creating more externalities. This is the fallacy that lies at the heart of much current policy. All regulations that restrict actions by private parties or restrict the alienability of rights create such externalities, and thereby reduce economic efficiency, wealth and freedom': ibid.

${ }^{76}$ This would entail a cost-benefit analysis; in the context of tackling fraud this may be done by measuring the cost of fraud (to ascertain the benefit that would be gained if such fraud did not occur), weighed against the cost of regulation (including fees and other costs that would be incurred by firms in order to comply with new regulations): Dyck et al (n 35), 30. In the BHS case, costs incurred by the pensions regulator were significant: 'each Warning Notice was over 300 pages long and set out the background, specific evidence and legal arguments as to why we considered it reasonable for the respondents to have to support the schemes. The Warning Notices were also accompanied by a bundle of supporting evidence and expert reports amounting to approximately 13,000 documents in total': Regulatory Intervention Report (n 39), 31.
} 
'killing through regulation the goose that lays the golden egg', by crushing the creativity and innovation that drives new and evolving economic models. ${ }^{77} \mathrm{~A}$ more nuanced approach must consider what degree or intensity of regulation is required in constructing a coherent legal system. To apply that approach in the context of protecting stakeholder interests in corporate governance, it is necessary to revisit the interaction between legislation and private law principles in governing market transactions.

\section{Private law and wealth egalitarianism}

It is axiomatic that no market economy is perfectly free. Nevertheless it is readily observable that the greater the degree of economic freedom the more likely a country is to be prosperous; the converse is also true as command and control economies tend to be mired in decline. Even without making any claims about causation, these persistent correlations lend weight to the argument that if economic freedom based on private ordering tends to maximize productivity, wealth and aggregate social welfare then the public-welfare outcomes of private decision-making are likely to be superior to the outcomes that can be achieved through legislative fiat. This debate has by no means been settled by the deregulation and reregulation trends of recent decades; the preference for self-regulating open markets still goes a long way in explaining the predominance of default or opt-out rules in company law and the orthodox conceptualization of the corporation as a network of contracts. ${ }^{78}$ It would be quite wrong to suppose that because the principles of private law in common law jurisdictions were largely developed by the courts in the nineteenth century at the height of the industrial era, this means that they no longer have much resonance in today's post-industrial world. In fact the ideals of freedom of contract and the sanctity of private property, together with a seeno-evil approach to socio-economic inequality, continue to reverberate in the modern

\footnotetext{
${ }^{77}$ R Epstein, 'Uber and Lyft in California: How to Use Employment Law to Wreck an Industry', Forbes (Mar. 16, 2015, 10:57 AM), http://www.forbes.com/

${ }^{78}$ Bainbridge ( $\mathrm{n} 13$ ).
} 
debates. ${ }^{79}$ The doctrine of private property, in particular, still provides much of the conceptual underpinning of the law in capitalist systems. ${ }^{80}$

These rationales explain the priority accorded by incorporation statutes to shareholder decision-making, and why little is said about social welfare implications of corporate activity beyond requiring directors to consider a range of stakeholder interests when deciding what is in the best interests of the company. Although it is arguable that multi-stakeholder entitlements can be grounded in private law concepts, ${ }^{81}$ enthusiasts of the private law framework are generally unconcerned about the moral and political distributional controversies that trouble policy-makers because the efficiency of the common law evolutionary process is thought to produce rules which optimize outcomes for society as a whole. ${ }^{82}$ The difficulty with the efficiency thesis is that the envisaged optimality focuses on productivity and remains indifferent to the distributive questions prioritized by egalitarian theories of justice. That indifference is often justified by arguing that productivity gains in the economy should be welcomed even if the proportion enjoyed by individual citizens is not precisely equal. ${ }^{83}$ But in a context where 'fairness' is widely understood to encompass 'equality' it is doubtful that self-regulating corporations would ever have sufficient incentives

\footnotetext{
79 It is scarcely credible today, with a strong ethos of employment protection reflected in the law, that indifference to inequality has historically been defended in courts of law: 'No doubt, wherever the right of private property exists, there must and will be inequalities of fortune...And since it is self-evident that, unless all things are held in common, some persons must have more property than others, it is from the nature of things impossible to uphold freedom of contract and the right of private property without at the same time recognizing as legitimate those inequalities of fortune that are the necessary result of the exercise of those rights' Coppage $v$ Kansas 236 U.S. 1 (1915), 17. For a contextual discussion of this case see LE Blades, 'Employment At Will vs. Individual Freedom: On Limiting the Abusive Exercise of Employer Power' (1967) 67 Columbia Law Review 1404. 80 'Private property capitalist systems are distinguished by the fact that most decision rights are assigned to private individuals or organizations. In contrast, socialist or communist systems assign most decision rights to the state or the governing party': MC Jensen, 'Freedom, Capitalism and Human Behavior: Capitalism' (1999) Harvard Business School NOM Unit Working Paper No 1999, 2, available at https://papers.ssrn.com/sol3/papers.cfm?abstract_id $=638802$

${ }^{81}$ W Njoya, Property in Work: The Employment Relationship in the Anglo-American Firm (Aldershot, Ashgate 2007).

${ }^{82}$ Conversely, 'The policy maker is concerned not only with optimal allocation of resources but also with the appropriate distribution of resources as determined by moral and political criteria; he must have regard to the effects on income and wealth of a particular decision on allocation': Al Ogus, 'Economics, Liberty and the Common Law' (1980) 15 Journal of the Society of Public Teachers of Law 42, 53.

83 'Of the tendencies that are harmful to sound economics, the most seductive, and in my opinion the most poisonous, is to focus on questions of distribution...The potential for improving the lives of poor people by finding different ways of distributing current production is nothing compared to the apparently limitless potential of increasing production': RE Lucas Jr, 'The Industrial Revolution: Past and Future' (2003) Annual Report Essay, The Federal Reserve Bank of Minneapolis available at https://minneapolisfed.org/publications/theregion/the-industrial-revolution-past-and-future.
} 
to align their distributive choices with public expectations of fairness as equality. This, then, is a debate with deep philosophical roots that is by no means settled. As the controversy rages, it becomes increasingly important to re-evaluate the role that should be played by corporate law.

Central to the corporate governance debates is the failure of its predominantly private law tenets to address the concerns of Rawlsian wealth egalitarians who, if it came to a choice, ${ }^{84}$ would prefer equality as a component of social justice to be prioritized above productivity and growth. ${ }^{85}$ In that context it is often argued that social justice, not efficiency, should be the primary concern for law and policy-making ${ }^{86}$ and that principles of equality are an essential component of any theory of justice. As private ordering does not allow much scope for dealing explicitly with questions of distributive justice, egalitarians often argue that ultimate decision-making power should vest in the state or government in order to meet the demands of fairness. ${ }^{87}$ In a time when these perspectives are ascendant and inequality is widely considered to be the most urgent problem facing industrialised societies, the legal framework regulating companies looks increasingly outmoded and anachronistic to the extent that it says nothing about how it will contribute to a more equal society. As observed earlier, the mounting pressure for regulation to play a more proactive and interventionist role in redressing the gap between rich and poor both at the national and global levels is partly

\footnotetext{
${ }^{84}$ It does not invariably come to a choice; it is often possible to pursue both efficiency and equality through ideas such as 'enlightened shareholder value' which recognize that the most profitable businesses are often those who prioritize the welfare of all their stakeholders. For a discussion see S Deakin and A Hughes, 'Economic Efficiency and the Proceduralisation of Company Law' (1999) 3 Company Financial and Insolvency Law Review; and more generally S Hsu, 'Inefficient Inequality' (2016) 5 Indiana Journal of Law and Social Equality 1 arguing for a better balance between efficiency and equality: 'I emphasize that this Article does not argue that inequality is per se inefficient. Juxtaposed against the arguments raised in this Article are a countervailing set of arguments that inequality is not only something to be tolerated but even a necessary ingredient for prosperity', 4 .

${ }^{85}$ For instance, as will be discussed later, Atkinson argues that 'a smaller cake more fairly distributed may be preferable to a larger one with present levels of inequality': AB Atkinson, Inequality: What Can Be Done? (Harvard University Press 2015), 243.

86 'Even if...the common law is efficient, that still leaves open the question whether that makes it "superior" law....even supposing that the common law were more efficient, the policy maker might not find it acceptable as it conflicts with current notions of social justice. That legal education and the theories of law should be preoccupied with economic efficiency rather than with social justice is, I would suggest, almost a contradiction in terms': Ogus (n 82), 53, 54.

87 Referred to by Ogus as 'the law of regulation' which 'intervenes in the free enterprise process either by adjusting the market mechanism through, for example, price or wage fixing, taxation, licensing, quality controls or, more drastically, by replacing the market mechanism altogether' (Ibid, 47).
} 
driven by accusations that law is itself complicit in exacerbating the causal and contextual factors of economic inequality.

To respond to those concerns this discussion draws inspiration from John Tomasi's efforts to develop a theory of 'free market fairness' that draws upon Rawlsian interpretations of justice as fairness but constructs a humanitarian rather than egalitarian concept of social justice. ${ }^{88}$ The humanitarian conceptualisation of social justice does not regard distributional questions as dispositive; instead, the implication is that:

'Social justice is a property not of particular distributions, but of social institutions taken as a whole. As such, a demand for social justice does not necessarily call for (or allow) immediate state action to adjust or "correct" particular distributions. Social justice requires that one take a longer view. It is a standard that tells us what sort of macroinstitutional forms we should work towards'. ${ }^{89}$

From that perspective, the evaluation of regulatory interventions aims to ensure that social legislation preserves a meaningful scope for economic liberty and private decision-making. Anthony Ogus viewed this contestation as one involving a dual function: 'the law's conservative role is to maintain liberal and individualist values; its dynamic role is to act as an instrument of redistribution. Though different in character, these two functions are of equal status: they should attract the attention of the jurist in equal measure. ${ }^{\prime 90}$ Although Ogus approaches this contestation from the converse approach, ie in order to emphasize the dynamic role of law as he sees it, his insight regarding the dual function of law is highly instructive in this context. This may be elucidated by the distinction Ogus draws between a 'market system' in which the parties are free 'to pursue their own welfare goals' through private transactions and a 'collectivist system' in which 'the state seeks to direct or encourage behaviour which (it is assumed) would not occur without such intervention' in order 'to correct perceived deficiencies in the market system in meeting collective or public interest goals'.$^{91}$ This is not a straightforward contest between 'regulation' and 'deregulation', but

\footnotetext{
${ }^{88}$ Tomasi (n 22).

89 ibid, xix.

90 (n 82), 54.

${ }^{91}$ Al Ogus, Regulation: Legal Form and Economic Theory (Oxford, Hart Publishing 1994) 1, 2.
} 
rather merits closer analysis of intricate questions concerning the specific types of regulation that work best and identifying the situations in which such regulation can or should be adopted. Nor is this duality an attempt to forge an uneasy compromise between capital and labour by emphasizing superficial mutual goals while papering over deeply rooted conflicts of interest and overlooking their incompatible moral commitments..$^{92}$ Rather than attempting to reconcile incompatible ideologies, that duality acknowledges the strength of each perspective in its own right, and juxtaposes each perspective against the other in order to acquire a richer understanding of the policy priorities that should be pursued in particular contexts and how best to achieve the intended outcomes through tailored legal interventions. Framed in that way the debate then concerns identification of the appropriate regulatory interventions in balancing corporate productivity with fairness for workers.

\section{Reconfiguring corporate regulation}

Assuming that it is not proposed to eschew capitalism altogether but instead to soften its harsher edges, mitigate its worst excesses, and include as many people as possible in the prosperity and abundance of economic growth, ${ }^{93}$ and acknowledging that large corporations function as the engine of modern capitalist economies, the question is how law can best pursue its social justice ideals without undermining the notions of individual economic liberty that drive the entrepreneurial spirit. This part of the discussion addresses that question by reference to the idea that the market-correcting function of legislation designed to meet social-welfare goals might be a useful way to define the role of law in regulating corporate

\footnotetext{
92 This uneasy compromise is reflected in ideas such as 'partnership' and 'flexicurity'; for a discussion of partnership see W Njoya, 'The EU Framework of Information and Consultation: Implications for Trades Unions and Industrial Democracy' in A Bogg, C Costello and A Davies, Research Handbook on EU Labour Law (Cheltenham, Edward Elgar 2016); for a discussion of 'flexicurity' see W Njoya, 'Job Security in a Flexible Labor Market: Challenges and Possibilities for Worker Voice' (2012) 33 Comparative Labor Law \& Policy Journal 459.

${ }^{93}$ This assumption is justified by the fact that some modern interpretations of socialism do not aim to displace markets altogether but instead to ensure that markets operate consistently with principles of social justice: 'My purpose, then, is to revise socialism not principally by critiquing central planning under the control of a dictatorial party - that would be, today, beating a dead horse - but to argue that the ethics of socialism should be reformulated, from being characterized as the elimination of exploitation, to the elimination of distributive injustice': J Roemer, 'Socialism Revised' (2017) Cowles Foundation Discussion Paper No 2089, 5. Thus the focus is less on public ownership and more on how non-market institutions such as democratic processes can help resolve market failures and harmful externalities: C Crouch, 'Entrenching Neo-Liberalism: the current agenda of European Social Policy' in N Countouris and M Freedland (eds) Resocialising Europe in a Time of Crisis (Cambridge University Press, 2013) 36. For the regulatory implications see R Epstein, Simple Rules for a Complex World (Harvard University Press 1995), 23; for discussion in the context of corporate decision-making see Bainbridge (n 13), 889.
} 
activity, particularly when corporate strategies have an adverse impact on jobs and employment security. Within that theoretical framework corporate decisions that exacerbate economic inequality might then be regarded as a signal of market failure. For instance, while it is true as observed at the height of the industrial era that in a free country 'it naturally happens that parties negotiating about a contract are not equally unhampered by circumstances $^{\prime 94}$ this inequality may be resolved by legislation designed to equalize the bargaining position of the parties through, for example, mandatory recognition of independent trade unions. ${ }^{95}$ If economic inequality can be interpreted in that way as a signal of market failure, then targeted legislation designed to implement redistributive goals would be an appropriate response, and the justification for imposing restrictions on how the company allocates its profits would be self-evident. But the matter is not that simple. Addressing the needs of those who are deemed to suffer from the identified market failure should be viewed as one step along the road to achieving prosperity for all. Without that longer-term framework the attempt to correct a narrowly and perhaps temporally defined market failure may simply trigger a new set of deeper and more serious problems.

This difficulty is well illustrated by the debates surrounding executive compensation. Following persistent claims that senior executives are overpaid at the expense of the company and its stakeholders, the law in various jurisdictions attempts to divert the company's profits away from greedy executive pockets by direct measures such as caps on executive pay or indirect measures such as shareholder oversight of the corporation's remuneration policies and procedures. ${ }^{96}$ The arguments usually cited in favour of stricter regulation of executive compensation rely on notions of corporate accountability, the reasoning being that the privileges of incorporation and limited liability, coupled with the inordinate power and wealth vesting in large corporations, together give rise to a corresponding moral duty to hold themselves accountable to society. ${ }^{97}$ This in turn leads to the argument that such

\footnotetext{
94 'and thus it naturally happens that parties negotiating about a contract are not equally unhampered by circumstances. This applies to all contracts, and not merely to that between employer and employee...': Coppage $v$ Kansas (n 79).

95 Trade Unions and Labour Relations (Consolidation) Act 1992; for a discussion see A Bogg, Democratic Aspects of Trade Union Recognition (Oxford, Hart Publishing 2009).

${ }^{96}$ For such regulatory approaches in the US see Murphy (n 50); in the UK see A Dignam, 'Remuneration and Riots: Rethinking Corporate Governance Reform in the Age of Entitlement' (2013) 66 Current Legal Problems 401.

97 J Parkinson, Corporate Power and Responsibility: Issues in the Theory of Company Law (Oxford University Press 1993).
} 
accountability extends to taking steps to reduce or at least not to exacerbate economic inequality: the putative social responsibility of corporations. Hence one of the key proposals in the recent corporate governance reform consultation in the UK concerned regulating executive pay, and was presented as a way of holding corporations accountable for their contribution to rising income inequality by mandating the disclosure of pay ratios. ${ }^{98}$ The regulatory approach here relies heavily on disclosure rules: by disclosing their pay policies and remuneration packages corporations open themselves to scrutiny by their shareholders and the general public. That approach has so far enjoyed limited success, primarily because of its reliance on the exhortatory language of social responsibility or even, as expressed by the Supreme Court of Canada, the obligation to be a good corporate citizen. ${ }^{99}$ This 'good citizen' language overlooks the reality of fragmented shareholders dispersed across the globe, including foreign sovereign wealth funds, who are granted by law the exclusive right to elect directors even though they view their investment as purely financial and have no rational reason to be interested in the social welfare effects of directors' decisions. ${ }^{100}$ In the result, nothing much changes and the 'corporate social responsibility' initiatives have by now lost much of their persuasive force. A fresh approach is needed.

This is an area where both company law and labour law play a key role. A more joined-up approach between the two fields would suggest that a good place to begin, in thinking about how to reconfigure the legal framework, is by turning our attention to the concept of economic wellbeing as a unifying goal. The next part of the discussion argues that it is in the interests of both labour and capital to prioritize freedom from poverty and protection of vulnerable workers alongside sustainable economic growth and prosperity with consistently rising standards of living. Neither side of this debate is opposed to these goals - they are

\footnotetext{
98 'The Government intends to introduce secondary legislation to require quoted companies to report annually the ratio of chief executive total remuneration to the average pay of the company's UK employees, and to set out more clearly in remuneration policies the impact of share price growth on long-term executive pay outcomes': (n 57).

${ }^{99}$ BCE Inc v 1976 Debentureholders [2008] 3 SCR 560; for discussion see E Waitzer and J Jaswal, 'Peoples, BCE, and the Good Corporate "Citizen"' (2009) 47 Osgoode Hall Law Journal 439.

100 The problem of rational shareholder apathy and the changing landscape of shareholding including the shift of power from institutional shareholders to private hedge funds is discussed by PL Davies, 'Shareholders in the United Kingdom' in RS Thomas and JG Hill (eds) Research Handbook on Shareholder Power (Cheltenham, Edward Elgar 2015), 355.
} 
simply not agreed on the best means to achieve them and how to set the relevant policy priorities in line with their respective moral commitments.

\section{A broader conceptualization of economic wellbeing}

'Economic growth is the engine of the escape from poverty and material deprivation'. ${ }^{101}$

For too long economists preoccupied with economic growth and productivity have been inattentive to wealth distribution. Defenders of free markets are tempted towards the view that unequal distribution is insignificant precisely because they are enamoured of the exponential economic growth sparked by industrial and technological innovations. This perspective is not difficult to understand, if one considers for example the dominance of corporations such as Google or Apple in the modern consumer lifestyle. For their employees, large corporations offer attractive perquisites such as healthcare benefits, on-site childcare for pre-schoolers, subsidies for the costs of housing, free transportation, free gym membership, and the like, benefits which are not required by law and add considerably to the economic welfare of their employees. In that context, worrying about the pay ratio between their CEOs and the average employee might seem somewhat churlish. Large firms are attractive employers precisely because the average pay they offer is generally higher than that in smaller firms, especially when bonus payments and other wage-related benefits are taken into account; but higher relative pay in such firms does seem to come hand in hand with a larger gap between the average and the highest wage in the firm. ${ }^{102}$ If large firms exhibit higher average wages alongside rising wage disparity it seems that the greater potential for all workers to earn more money comes bound with the likelihood of greater overall income inequality due to the stratospheric wages earned by executive managers.

Critics would like to see a more equal division of corporate profit between senior executives and ordinary employees, or a more equal distribution of returns to private shareholders and the public purse through corporate taxes. Such critics pay little or no heed to exponential growth or the creation of new and lucrative job opportunities, as they would argue that

\footnotetext{
${ }^{101}$ Deaton (n 2), xi.

102 S Davis and J Haltiwanger, 'Employer Size and the Wage Structure in U.S. Manufacturing' (1995) NBER Working Paper No. 5393.
} 
increased productivity and economic growth are unsustainable in the longer term if they exacerbate the growing gap between rich and poor. They would argue, like the Pope Francis in his critique of the 'economy of exclusion', that pursuing economic growth must embrace all members of society including those who are poor or socially vulnerable. ${ }^{103}$ This approach attaches significance to the fact that rising prosperity disproportionately benefits those people, and indeed nation states, who are already privileged in enjoying greater wealth than the vast majority of poor people and poor countries. As observed in the Introduction, Deaton has a different perspective on the inequality that follows in the wake of progress: he points out that no form of progress has yet been invented that benefits everybody at once, at the same moment in time, and in equal measure. He therefore argues that if progress leaves some people behind at least in the immediate term that is no reason to denigrate the human aspiration to improve material conditions from which everyone will eventually benefit. These realities are inextricably bound together in the complexity of the human condition, hence Deaton's observation that 'the tale of progress is also the tale of inequality.' ${ }^{104}$ The correct response, in Deaton's view, is not to decry the fact that progress leaves some behind due to multiple causes whether deserved or undeserved, but instead to formulate effective means by which to improve the lives of those left behind based on priorities that those people would consider meaningful (including non-monetary and non-income aspects of wellbeing such as access to health, education and free public amenities) rather than striving towards an unreachable ideal of equality.

The efforts of Atkinson and others to put wealth distribution on the policy agenda have undoubtedly transformed our understanding of the scope of inequality within and across countries. ${ }^{105}$ But egalitarian interpretations of the significance of the available data do not command universal agreement. One of the contentious issues relates to the fact that poverty is a relative concept, hence growing prosperity may well, and often does, go hand in hand with rising inequality. Everyone is better off, and there are fewer people living in absolute

\footnotetext{
103 C Clark, 'Economy of Exclusion: Global Perspectives on Pope Francis on Capitalism' (2017) 2 Journal of Vincentian Social Action 4.

104 (n 2) xii.

105 W Salverda, B Nolan and TM Smeeding, Oxford Handbook of Economic Inequality (Oxford University Press, 2009). See further Atkinson (n 85).
} 
poverty, but the relatively poor are slightly better off while the relatively rich are much better off:

'In effect, world economic growth, though strongly inegalitarian, contributed to a steady decline in the headcount measure of poverty throughout the period under analysis. Over the 172 years considered here, the mean income of world inhabitants increased by a factor of 7.6. The mean income of the bottom 20 percent increased only by a factor of slightly more than 3 , that of the bottom 60 percent by about 4 , and that of the top decile by almost 10 . At the same time, however, the extreme poverty headcount fell from 84 percent of the world population in 1820 to 24 percent in 1992.'106

For the wealth egalitarian, economic prosperity that does not bring greater equality is nothing to celebrate. The implication is that if higher average wages in large firms are correlated with an increasing spread in wage distribution, it would be justifiable from an egalitarian perspective to shrink wages if necessary in order to achieve greater equality of pay. ${ }^{107}$ Hence in formulating redistributive policy proposals Atkinson argues that 'a smaller cake more fairly distributed may be preferable to a larger one with present levels of inequality' because, in keeping with Rawlsian theories of justice, fair distribution is as much a priority as economic growth, if not more so. ${ }^{108}$ In Atkinson's view the two factors go hand in hand as there must be 'an acceptable trade-off between efficiency and equity' and what makes the trade-off acceptable, in terms of social justice, is how fairly it redistributes wealth. Further, Atkinson would expect to see both gains and losses from wealth redistribution - so although economic growth might suffer in some respects, that might be offset by efficiency gains in other respects owing to factors such as enhanced levels of worker trust and loyalty. It is on this issue decisions about what makes the trade-off between efficiency and equity acceptable - that perspectives diverge. ${ }^{109}$

\footnotetext{
${ }^{106}$ F Bourguignon and C Morrisson (2002) 92 American Economic Review 727, 733.

107 Similarly, gender pay equality can be achieved by reducing men's pay: 'Six male BBC presenters agree to pay cuts' http://www.bbc.co.uk/news/uk-42827333.

108 Atkinson (n 85), 243.

109 At any rate it is not self-evident that political and moral considerations should override efficiency as a standard for triggering the coercive intervention of the state-backed authority of law. See Ogus ( $\mathrm{n} 82, \mathrm{n} 91$ ) for
} 
It is unlikely that divergent theories of moral philosophy will ever reach agreement on whether, or when, equality is more important than progress, but by framing the debate in terms of economic wellbeing it becomes easier to achieve consensus on the financial needs and priorities to be met by the public purse, which in turn has implications for levels of taxation and how public funds are allocated. Economic wellbeing is a sustainable goal to work towards, whereas the financial burden that must be incurred if the ideal of equality in economic life is set up as the relevant target is unlikely to be sustainable in the longer term. When the costs of achieving economic equality are taken into account it is easy to understand why the potential claims that may be made against wealthy corporations are uppermost in the minds of politicians who have promised their electorates that they can square the circle by delivering lower taxes, rising prosperity and greater economic equality. Dealing robustly with corporate scandals that impose huge social and financial costs on the public would go some way towards delivering on those promises, but a deficit inevitably remains. Should corporations therefore pay more to contribute to social welfare costs?

The answer will vary according to whether social welfare costs are computed by reference to the goal of achieving socio-economic equality, or by reference to improving economic wellbeing, since it is of course possible to achieve rising standards of living and a better quality of life without everyone having an equal amount of wealth. Holding this observation in mind will militate against the risk of losing sight of the very reason why inequality should matter at all: economic equality does not matter for its own sake, but because it offers a way to achieve human flourishing and fuller participation in social and economic life. ${ }^{110}$ Viewed in that way, the notion of economic wellbeing is critical not only for wealth egalitarians, but also for utilitarians seeking to maximize public goods to be enjoyed by as many people as possible. Apart from offering an achievable goal around which consensus can be achieved, that

\footnotetext{
illustrative examples of how efficiency considerations leave open distributional questions that can only be resolved by reference to political and moral values.

${ }^{110}$ For purposes of thinking about economic development, equality is less interesting as an end in itself and more for what it helps us to achieve. Some of the relevant questions as framed by Deaton are: 'what inequality does, whether inequality helps or hurts, and whether it matters what kind of inequality we are talking about. Does society benefit from having very rich people when most are not rich? If not, does society benefit from the rules and institutions that allow some to get much richer than the rest? Or do the rich harm everyone else - for example by making it difficult for the nonrich to affect how society is run?' (n 2), 11, 12.
} 
approach has the added advantage of curbing the quite unaffordable thirst for ever more public spending designed to put everyone in society in an equal economic position.

In working towards the goal of economic wellbeing wage disparities certainly matter, but consumption patterns and the overall standard of living are much more important. Consumption measures include factors reflecting family wellbeing such as 'food at home, housing and vehicles' and also take into account tax credits, non-cash benefits, access to sources of credit including affordable loans, and social security claims guaranteed by the state. ${ }^{111}$ Bruce Meyer and James Sullivan have captured the importance of these factors particularly for those who are socially marginalized; they show that 'consumption is a better predictor of well-being than income for those at the bottom' especially 'single parent headed families and single individuals, who have the largest increases in income inequality, but the largest declines in consumption inequality.' ${ }^{112}$ These groups may seem much worse off when compared to the richest members of society, but over time they are becoming much better off in terms of their own quality of life and standard of living. In encompassing a wider set of variables including measures of consumption, the material standard of living, and prospects for advancement over time, the main implication for the legal regulation of the work-wage bargain lies in recognising that income is only one source of wealth, and not always the most important one, when evaluating the benefit derived by the worker from a particular job: 'While wages are an important component of overall economic well-being, other factors also contribute to well-being such as unemployment, disability, retirement, family formation, child bearing, health, transfers from family, friends and government, and saving and borrowing. ${ }^{\prime 113}$ If the wage is not itself the most important factor, the ratio between that wage and the boss's wage becomes even less material.

In that light it is not only relevant but indeed highly significant to consider, in assessing the significance of rising income inequality, not only how a CEO's wage compares to the average wage in his own firm but also how the lowest wages in his firm compare to the wages of

\footnotetext{
${ }^{111}$ B Meyer and J Sullivan, 'Consumption and Income Inequality in the U.S. Since the 1960s' Becker Friedman Institute for Research in Economics, University of Chicago, Working Paper Series No. 2017-12, 2. See also their argument that 'conceptual arguments as to whether income or consumption is a better measure of material well-being almost always favor consumption', 7 et seq.

112 Ibid, 7, 3.

$113 \mathrm{lbid}$. Bourguignon and Morrisson also argue that 'Income is only one dimension of economic well being. Any analysis of the evolution of world inequality should also take other dimensions into account': (n 106), 728.
} 
comparable workers in the wider economy. That would give a more nuanced and instructive picture of the wage structure of the firm as a whole. Headlines about the growing ratio between executive pay and the average wage paid by a firm should be viewed alongside consumption trends and patterns. ${ }^{114}$ High pay understandably attracts more attention than consumption because it is easier to define and measure, while the myriad variables affecting economic wellbeing are less straightforward to capture than the facts and figures contained in income tax records relied on by income inequality studies. But in reality both consumptionbased and income-based measures are incomplete. ${ }^{115}$ Many elements of human flourishing are hardly measured at all, such as the benefit of widely available and virtually free online platforms offered by companies like Google, which make it easier for the unemployed to escape from social exclusion and make connections with the world of work that would have been inaccessible before the digital revolution and therefore now go a long way towards raising levels of both income and consumption. As Deaton observes:

'the information revolution and its associated devices do more for wellbeing than we can measure. That these pleasures are barely captured in the growth statistics tells us about the inadequacies of the statistics, not the inadequacies of the technology or the joys that it brings' ${ }^{116}$

Taking this into account, it becomes apparent that the problem of inequality is not as linear as the income-based studies imply, in so far as they obscure the evidence of less disparity in consumption patterns. By highlighting the increasing scope of material, physical and psychological flourishing in an increasingly affluent world, a more comprehensive evaluation can be made of the role played by private companies in contributing to social welfare.

It is often feared that the benefits of living in an affluent society, or the creation of jobs in the new economy offering attractive salaries, pensions, job-related perquisites and enhanced employability opportunities including training and skills enhancement, only benefit the elite

\footnotetext{
114 'Although over the long run consumption should come quite close to permanent income...there can be considerable deviations in the short run...Consumption is thus generally considered a better measure of current welfare than income': FHG Ferreira and M Ravallion, 'Poverty and Inequality: The Global Context' in Salverda et al (n 105), 599, 601.

${ }^{115}$ Nancy Folbre argues that measures based on income and consumption are both 'seriously incomplete' in so far as they leave out 'production and consumption within the household' through household activities that 'represent implicit income' such as accommodation and meals provided by family members or income-saving work done within the home: 'Inequality and Time Use in the Household' in Salverda et al (n 105), 342.

116 (n 2) 327, 328.
} 
and privileged high earners. There are also concerns that even though corporate benefits may be broadly enjoyed, the nuclear fallout of corporate scandals extends far beyond the initial events to create financial instability and ultimately greater socio-economic inequality that overrides any welfare gains that might previously have been realized. In that context, what should be done about those who are left behind by the great march of progress? To address these concerns, the final part of this discussion considers whether large firms contribute sufficiently to the social welfare costs of those who need assistance when they fall on hard times. The argument is that law and regulation should navigate between enhancing the social welfare contributions of firms through tax-related legislation and supporting the company's internal provision of on-the-job welfare benefits offered to their employees so that one does not come at the expense of the other.

\section{Implications for the welfare state}

The deleterious effects of economic inequality are in theory mitigated by the welfare state, as governments draw upon public funds to provide a safety-net for the poorest and most vulnerable in society. In the context of corporate failure, costs such as unemployment insurance and pensions are therefore, to an extent, covered by public funds. One of the challenges posed by the gig economy is that such costs are becoming unsustainable as large corporate employers increasingly embrace the on-demand digital economy with the attendant reclassification of workers as 'self-employed' for tax and social security purposes despite being classified as 'workers' for purposes of employment protection. ${ }^{117}$ Social welfare provision is inevitably affected by the changing characterisation of the employment relationship and specifically the interpretation of the contract of employment. Just as the poor law statutes which preceded the emergence of the modern welfare state were pivotal upon the annual service to establish entitlement to poor relief, ${ }^{118}$ in the modern era social security payments during insolvency or after retirement have relied on the status of the

\footnotetext{
${ }^{117}$ S. 230 Employment Rights Act 1996: a 'worker' is an individual who works under either a contract of employment (i.e. is an 'employee') or works under 'any other contract... whereby the individual undertakes to do or perform personally any work or services for another party to the contract whose status is not by virtue of the contract that of a client or customer of any profession or business undertaking carried on by the individual'; for an interpretation of this provision see Clyde \& Co LLP v Bates van Winkelhof [2014] UKSC 32. 118 S Deakin, 'The Comparative Evolution of the Employment Relationship' in G Davidov and B Langille, Boundaries and Frontiers of Labour Law: Goals and Means in the Regulation of Work (Oxford, Hart Publishing 2006).
} 
'employee' as the primary guarantor of income security. The role played by the large corporation as employer of a significant percentage of workers is therefore central to the debate about the future of the welfare state.

The growing financial burden imposed upon the welfare state by increasing numbers of selfemployed workers is part of a trend witnessed in recent decades as long-term secure employment fades into history. These concerns were the focus of the recent Parliamentary Select Committee Report (the Field Report), which observed that developments in the gig economy have compounded these challenges by creating even more opportunities for corporations to shed financial obligations typically based on the employment relationship. ${ }^{119}$ The aim of corporations in treating their labour force as self-employed is of course to reduce the cost of labour, hence it is perhaps inevitable that the debates surrounding these developments have become 'politically polarized' as 'the classification of workers has been characterized, perhaps caricatured, as a clash of free-market principles and worker protections'. ${ }^{120}$

Given the scope for avoidance of income tax and other social security payments, as well as the risks posed to 'independent' workers if the employer classifies them outside the full protective scope of employment law, the Field Report sought ways to 'protect them from hardship and the welfare state from costs'. ${ }^{121}$ The Field Report highlights the unravelling of the 'social contract' underlying the welfare state since its early roots in the Beveridge Report of 1942, observing that this contract has come under pressure in recent years with more people expecting to take out from the system but increasingly fewer people paying in. The Report observes that without an overhaul of the old social contract the public purse will buckle under the weight of the increasing financial claims being made against it. It is significant, as observed by the Field Report, that while the focus before 1942 was on lifting people out of poverty, deprivation and want, the modern era of rising prosperity has witnessed a widespread shift in public expectations away from concerns about deprivation

\footnotetext{
119 House of Commons, Work and Pensions Committee Report on Self-Employment and the Gig Economy (May 2017): 'The ease with which companies are able to classify their workforces as self-employed both fails to protect workers from exploitation, and potentially increases strain on the welfare state': 3.

${ }^{120}$ Means and Seiner ( $\left.\mathrm{n} 10\right), 1515,1516$. They observe that 'Employees cost more than independent contractors because businesses are responsible for, among other things, payroll taxes, workers' compensation insurance, health care, minimum wage, overtime, and the reimbursement of business-related expenses': 1513, 1514.

${ }^{121}$ Report on Self-Employment (n 119), 3.
} 
and more towards attaining the ideals of economic equality. The goal today is to create a society where nobody is vastly richer than other people as framed in the popular slogan that 'we are the $99 \%$ '. 122

Social welfare, formerly understood as a safety-net to prevent citizens from falling into poverty or help them to rise out of poverty, now has a greater significance beyond specific payments made in a time of need and is widely regarded as one of the tools available to the government to help achieve greater social and economic equality. This shift has played a role in contributing to the 'something for nothing welfare society' ${ }^{123}$ as the notion of paying in to the system under a form of social contract seems quite meaningless if the goal is to ensure that everyone should ultimately benefit equally in virtue of their humanity and not in virtue of their contribution to the system. As Field observes, the decoupling of welfare pay-outs from contributions and the resulting rise in public spending crosses party-political lines; the Labour Party began by 'arguing that equality, not nationalisation, was the party's goal, and the route to equality was greater public expenditure', an electoral policy that was soon copied and indeed surpassed by the Tories so that eventually 'a ratchet effect that locked in rising public expenditure was politically institutionalised between the two major parties' ${ }^{124}$ In that context, what contribution ought to be made by private companies to help offset rising social welfare costs? Should they be required to join in the institutionalisation of rising expenditure on social welfare based on achieving economic equality for all regardless of their contribution? If the question is framed primarily as one concerning the redistribution of wealth, then the ratchet effect seen in the political sphere would extend in exactly the same way to private employers. If citizens expect to receive higher levels of public welfare support without worrying too much about where the money will come from, ${ }^{125}$ then it is not much of a leap to expect corporations to create jobs, turn healthy profits, survive in a competitive

\footnotetext{
122 In America, which is perhaps the most capitalist of capitalist nations, it has been observed that fortunes change, or may change, so much over a lifetime that income categories are not static and the class of the $99 \%$ is a class with fluid members: 'class in America is much more complicated than a simple story of the $1 \%$ against the $99 \%$. Why aren't Americans taking to the streets, ready to fight the next class war? It's because many of us wouldn't know which side we're on': C Matthews, 'The Myth of the 1\% and the 99\%' Fortune, March 2, 2015. ${ }^{123} \mathrm{~F}$ Field, Working Welfare: Contributory Benefits, the Moral Economy and the New Politics (London, Politeia 2013), 12.

$124 \mathrm{Ibid}$, 5. Field observes that 'taxpayers, led by governments, have become accustomed to requesting Scandinavian levels of welfare but are, encouraged by decade upon decade of political dog whistling, to believe that this goal can be achieved by paying American levels of taxation': ibid, 11.

${ }^{125}$ Described by Field as a 'money goes on trees' expectation among many voters, encouraged by politicians of all parties making unaffordable promises when seeking re-election: ibid.
} 
global market, and at the same time take steps to equalize income on the simple basis that, as argued by the litigants in the Uber case, 'You can't have a company making millions and workers working below minimum wage. ${ }^{126}$

This discussion has argued that this is entirely the wrong approach. Instead, a more complete analysis of the public welfare function served by corporations is called for: new jobs, higher rates of employment income, work-related benefits including skills training, and workplace pensions are all relevant. ${ }^{127}$ This contributes to the economic welfare of significant numbers of workers: taking the example of London, over half of all private sector workers are employed by large firms. ${ }^{128}$ It is true that large corporations are notorious for doing everything within the law to reduce their tax payments, but unless the law has actually been broken this is no reason to ignore corporate tax payments when evaluating the contribution of large companies to public welfare. ${ }^{129}$ In sum, the need to constrain financial scandals or 'excessive' executive pay should not obscure the very real advantages represented by the presence of a vibrant and successful corporate and financial sector. In evaluating the functioning of capitalism, showcasing the overpaid fat cats is very revealing ${ }^{130}$ but that cannot be relied upon as a basis for legal and regulatory reform. At the same time, painting a more intricate and hence more informative picture of the role played by corporations in capitalist systems need not entail reverting to the opposite extreme, going back to the era when economists paid no attention to questions of distribution; ${ }^{131}$ the point being advanced here is a call to think more carefully about the balance between equality and economic freedom and the role played by the welfare state in relation to both goals.

\footnotetext{
${ }^{126} \mathrm{~L}$ Dearden, 'Uber ordered to treat drivers as workers with full rights after losing appeal in landmark case' The Independent, $10^{\text {th }}$ November 2017. The question posed by Field in the context of the welfare state then has even wider resonance: The need to link inputs with outputs applies just as much to expectations of corporate largesse as it does to social security claims on the public purse.

127 In addition to tax and social insurance payments, the Pensions Act 2008 requires every employer in the UK to provide a pension scheme for any employee earning over $£ 10,000$ per annum. Contributions are made by employer, employee, and the state.

128 R Prothero, 'Employment in London by Firm Size' Working Paper 31 (London, Greater London Authority, 2008).

129 'An important limitation of the official statistics is that they do not account for tax transfers' in measuring income inequality; hence 'the debate over inequality relies almost exclusively on income data. Official income statistics indicate that inequality has increased sharply. But these official statistics may not accurately reflect changes in wellbeing. They ignore taxes and transfers and rely on income that is badly reported in surveys' Meyer and Sullivan (n 111) 1.

130 Njoya (n 16).

${ }^{131}$ AB Atkinson, 'Bringing Income Distribution in from the Cold' (1997) 107 Economic Journal 297.
} 
To strike such a balance, the implications for the legal conceptualization welfare state must also be considered. Until now it has not been necessary for legal scholars concerned with economic development to think in any specific way about the welfare state, the role it plays in providing income security, and how that affects the employment relationship. Although it has long been recognized that for many workers an important source of income security is rooted in social welfare benefits guaranteed by the state, ${ }^{132}$ legal scholarship has tended to skirt around social security matters. As Anthony Ogus observed many years ago, the tradition in academic law has been to regard social security regulations as less worthy of intellectual study than the legal interpretation of contractual relationships and the proprietary structure of organizations. ${ }^{133}$ But in recent years as employment law has attempted to develop a more varied classification of work relationships in order to try and extend the scope of employment protection, social security considerations have increasingly come into the spotlight as social security law has lagged behind clinging to the old dichotomy between employees and the selfemployed. ${ }^{134}$ Hence the importance of rethinking the nature of social welfare provision.

This discussion has suggested a helpful way to understand and depict the interactions between law and social security in this context. As defined by Field, the meaning of welfare encompasses 'the provision of cash and services which help to determine the living standards of individuals and families. ${ }^{135}$ Field's definition attributes welfare provision to five main sources: the traditional welfare state, tax allowances, company welfare in the form of workplace pensions and other benefits, inheritance and wealth passed down through family ties, and private market welfare such as private insurance. ${ }^{136}$ Any meaningful welfare system must therefore work well across all its facets to avoid overburdening any particular source. This highlights the need to redefine the aims and purposes of employers' financial contributions to public welfare levied directly through pension and social security

\footnotetext{
132 'Obviously a person's wage or salary cheque is important as are the whole range of social security benefits': Field (n 21), 16.

133 Ogus (n 82).

134 'This very significant crystallization of labour law's newly tripartite taxonomy of work relations has occurred very largely in the context of the on-demand economy, and is beneficial to those located in that sector. It will be argued that this is, however, a rather fragile conceptual structure, not least because there is a real tension between this system and the still bipartite system which is used to categorise the same set of work relations for tax and social security purposes': M Freedland and J Prassl, 'Employees, Workers, and the 'Sharing Economy: Changing Practices and Changing Concepts in the United Kingdom' (2017) 6 Spanish Labour Law and Employment Relations Journal 16, 17.

135 Field (n 21), 17.

136 ibid.
} 
contributions and indirectly through corporate taxes, and the importance of ensuring that the scope of welfare provision does not impose disproportionate costs on start-up firms in the new economy. The argument developed here implies that the nascent gig economy should not be met by law with a desperate attempt to cling to traditional forms of the employment relationship in the hope of shielding everyone from the pain of creative destruction, but instead should be seen as an opportunity to reimagine the role played by the welfare state and the way all citizens, including corporations, contribute to it.

As an increasing number of workers are categorized as self-employed by large corporations attempting to deliver their products at prices most consumers are happy with, as well as creating opportunities for many non-traditional workers to get involved in new forms of work, it becomes increasingly important to reconsider the role played by traditional forms of social welfare. The widespread outpouring of concern regarding the exploitation of workers, highlighted in a notable example by the ongoing litigation involving Uber, has prompted legal scholars to refocus their attention on the traditional distinction between dependent and selfemployed workers. ${ }^{137}$ But as firms like Uber continue to disrupt traditional certainties about the employment relationship, the narrative should not only be about the exploitation and suffering of workers. There is also another important side to the story: 'Advocates extol the potential of technological innovation to unshackle workers from the constraints of more traditional employment while, at the same time, unleashing the engines of capitalism to promote economic growth.' ${ }^{138}$ Thus the gig economy is the paradigmatic example of the problems depicted in this paper: it introduces flexibility and opportunity unknown before the digital age, and for that reason is being watched with interest in corners of the Third World that had previously been left behind by technological progress; at the same time it meets with censure from those concerned about worker exploitation and thereby creates a huge amount of confusion about whether all this progress is worth the social cost. In working out the answer to this dilemma, the test for external observers should not merely be whether new economic models help to reduce inequality, but also whether these models help to advance economic wellbeing.

\footnotetext{
${ }^{137}$ See, in the UK, Aslam v Uber BV [2017] IRLR 4, holding that Uber drivers are 'workers' falling within the scope of employment protection under the Working Time Regulations and the National Minimum Wage Act. 138 Means and Seiner (n 10), 1518.
} 


\section{Conclusion}

The increasing polarization of public discourse has impeded the exchange of ideas across the ideological divide regarding the costs and benefits of capitalism. From a legal perspective a similar polarization is evident between the fields of labour law and company law, where competing concerns about employment protection and corporate efficiency have given rise to a divergent set of priorities. This discussion has argued in favour of a different approach, by juxtaposing distributive justice with economic productivity, identifying some the implications of that contestation, and then proposing some ways of thinking about the desired outcomes more comprehensively by reference to consumption patterns and other non-monetary indicators such as access to education and health. This approach would reorient current debates about the interaction between employment protection and social security, highlighting the beneficial role played by the corporation in relation to the welfare of employees. To that end the discussion highlighted the dual role of large companies in exacerbating as well as mitigating various aspects of economic hardship, acknowledging the prevalence of costly scandals on the darker side as well as tax and social security contributions or work-related benefits and perquisites on the brighter side.

Given the place of large companies at the very heart of the capitalist economy, this approach yields deeper insight into the integrity and sustainability of capitalist economies, that is significant not only for law reform debates in liberal market economies but also for economic development debates in parts of the world that are still steeped in absolute poverty. This is particularly urgent in African economies that are not only poor, but actually marching relentlessly backwards crippled by persistent negative growth rates, and thus left behind by countries that are constructing their own varieties of capitalism. ${ }^{139}$ It would be unconscionable to send out the message that capitalism is an economic model that is socially harmful and therefore requires to be constrained by regulation as much as possible, when the truth is that such countries would benefit from entrenching basic principles of contract and private property to support the economic freedom that characterises competitive

\footnotetext{
139 'A group of Asian countries - China, Hong Kong, Malaysia, Singapore, South Korea, Taiwan, and Thailand - as well as one African country, Botswana, grew at more than 4 percent a year from 1960 to 2010...At the same time, the Central Africa Republic, the Democratic Republic of the Congo (DRC), Guinea, Haiti, Madagascar, Nicaragua, and Niger are actually poorer in 2010 than they were half a century ago' Deaton (n 2), 234, 235 (emphasis in original). For an exploration of different varieties of capitalism see PA Hall and D Sosckice, Varieties of Capitalism: The Institutional Foundations of Comparative Advantage (Oxford University Press 2001).
} 
markets. The lesson here is that it is critical for the legal framework to strike the right balance between social welfare and economic progress, and while the ideals of equality are valuable and worth pursuing, these ideals ought not to obscure the benefit to be gained by promoting economic wellbeing in a broader sense. For these reasons, in a time when there is no shortage of reports of corporate scandals in the daily press, this discussion has sought to highlight the merits of the acceptable face of capitalism. 